\title{
NASIONALISASI PERUSAHAAN-PERUSAHAAN ASING MENUJU EKONOMI BERDIKARI
}

\author{
Wasino \\ Jurusan Sejarah, Fakultas Ilmu Sosial, Universitas Negeri Semarang \\ swasino3@gmail.com
}

\begin{abstract}
After Indonesia declared its independence, the management of the private companies became a big problem for a new government, Indonesia. Expropriation efforts for those western private plantation companies actually had been developed in the first year of the independence and it continued until the Dutch-Indonesian Round Table Conference. There were three processes passed through companies' transformation of the western private plantation in Indonesia, namely decolonization, Indonesia-nization and nationalization. Nationalization was legally based on the Indonesian Ordinance number 86 1958, but the real process occured since a year ago. Therefore, Indonesia had to give financial compensation to the owner, but the reality was that this aspect was still unfinished until the end of Sukarno regime. The compensation had been continued in Suharto era and was fully paid in 2002.
\end{abstract}

Keywords: nationalization, indonesianization, berdikari

\begin{abstract}
ABSTRAK
Setelah Indonesia menyatakan kemerdekaannya, manajemen perusahaan swasta menjadi masalah besar bagi pemerintahan baru, Indonesia. Upaya pengambilalihan bagi perusahaan perkebunan swasta Barat sebenarnya telah dikembangkan pada tahun pertama kemerdekaan dan itu berlanjut hingga Konferensi Meja Bundar BelandaIndonesia. Ada tiga proses melewati transformasi perusahaan 'dari perkebunan swasta Barat di Indonesia, yaitu dekolonisasi, Indonesia-nization dan nasionalisasi. Nasionalisasi secara hukum berdasarkan jumlah Ordonansi Indonesia 86 tahun 1958, tetapi proses nyata terjadi sejak setahun yang lalu. Oleh karena itu, Indonesia harus memberikan kompensasi finansial kepada pemilik, tetapi kenyataannya adalah bahwa aspek ini masih belum selesai sampai akhir rezim Sukarno. Kompensasi telah berlanjut di era Soeharto dan telah dilunasi pada tahun 2002.
\end{abstract}

Kata kunci: nasionalisasi, indonesianisasi, berdikari

\section{PENDAHULUAN}

Proklamasi Kemerdekaan Indonesia memiliki makna politik, hukum, dan ekonomi. Secara politik, peristiwa tersebut merubahan perubahan atau peralihan dari zaman kekuasaan penjajah di Indonesia menjadi zaman baru, zaman merdeka, zaman yang secara politik Bangsa Indonesia berhak mengatur diri sendiri tanpa perlu menunggu restu dari kekuatan asing. Secara hukum, proklamasi dimaknai sebagai garis batas antara hukum kolonial menjadi hukum nasional. Sementara itu secara ekonomi, proklamasi dimaknai sebagai perubahan pengelolaan aset-aset ekonomi dari bangsa penjajah ke tangan Bangsa Indonesia.

Meskipun secara teoretik peristiwa proklamasi memiliki makna perubahan-perubahan tersebut, tetapi dalam realitasnya tidak demikian. Secara ekonomi ketika Indonesia merdeka hingga tahun 1950-an kekuasaan atas aset-aset ekonomi masih dipegang oleh orang asing. Jarinfan transportasi baik darat, laut maupun udara masih di 
bawah kendali kepemilikan asing. Perbankan yang menjadi faktor penting dalam menggarakkan ekonomi bangsa juga masih menjadi milik dan dikuasai oleh bangsa asing. Perusahaanperusahaan besar yang menggerakkan ekonomi modern seperti perkebunan tembakau, perkebunan tebu, perusahaan tambang, dan semacamnya juga masih menjadi milik asing yang secara hukum internasional mereka berhak atas aset-aset ekonomi mereka. Pendek kata secara ekonomi, selama beberapa tahun setelah Proklamasi Kemerdekaan, Indonesia belum merdeka.

Belenggu ekonomi asing di dalam negeri sendiri disadari oleh para pendiri bangsa. Mereka merasa diawasi oleh pelaku ekonomi asing di wilayah negerinya sendiri. Kekhawatiran mereka bukan tidak beralasan karena di tahun-tahun awal kemerdekaan Indonesia telah menghadai blokade ekonomi (Soejono dan Leirissa [ed], 2008). Sementara itu agresi militer Belanda tahun 1947 memiliki simbol khusus yang terkait dengan keberadaan aset-aset perusahaan Kolonial Belanda di Indonesia yang ditandai dengan simbol operasi khusus, yakni "Operasi produk" (Lindblad, 2008).

Riset tentang nasionalisasi telah banyak dilakukan. Salah satu hasil penelitian yang dilakukan oleh Wasino, dkk. pada tahun 2013/2014 (Wasino, dkk.' 2014). Artikel ini sebagian besar didasarkan pada hasil riset tersebut, dipadukan dengan hasil-hasil seminar yang dilakukan di Jurusan Sejarah UGM pada awal Januari 2015 dan Seminar yang diselenggarakan oleh Direktorat Sejarah, Dirjen Kebudayaan di Undip Semarang pada tahun 2015.

\section{METODE PENELITIAN}

Artikel ini didasarkan pada penelitian Sejarah Nasionalisasi Perusahaan Belanda menjadi Perusahaan Nasional Indonesia (Wasino, dkk, 2013). Dalam penelitian itu digunakan metode sejarah untuk proses pengumpulan data hingga pelaporan hasilnya. Dalam metode sejarah dikenal tahap-tahap penelitian, yaitu: penelusuran sumber sejarah, verifikasi atau kritik sumber, interpretasi dan eksplanasi, dan historiografi atau penulisan sejarah (Wasino, 2006:12).

Heuristik merupakan langkah awal dari penelitian ini yang berisikan kegiatan penelusuran sumber sejarah. Pengumpulan data dilakukan dengan metode penggunaan bahan dokumen. Penelitian dokumentasi dilakukan di sejumlah perpustakaan dan lembaga Arsip, baik di Indonesia maupun Belanda. Lembaga perpustakaan yang akan dikunjungi sebagai tempat penelitian adalah: Perpustakaan KITLV Leiden, Perpustakaan Universitas Leiden, Perpustakaan Universitas Amsterdam, Perpustakaan Nasional Jakarta, Perpustakaan Kementerian BUMN, Perpustakaan Departemen Dalam Negeri, Perpustakaan Badan Pertanahan Nasional, Perpustakaan Universitas Sumatera Utara, Perpustakaan Universitas Hasanudin. Penelitan di lembaga arsip meliputi: Arsip Nasional Belanda, Arsip Nasional Jakarta, Arsip Pertanahan di Badan Pertanahan, Badan Arsip Daerah di Semarang dan Yogjakarta. Sumber sejarah yang diteliti meliputi: surat kabar-surat kabar sezaman, proses verbal, data kepemilikan aset, dan data-data hukum tentang proses nasionalisasi.

Konsekuensi logis di dalam metode sejarah, setelah penulis berhasil mengumpulkan data yang diperlukan adalah melakukan kritik sumber, baik secara eksternal maupun internal. Kritik eksternal digunakan untuk menilai otentisitas sumber, sedangkan kritik internal digunakan untuk menilai kredibilitas sumber. Sumber dokumen yang 
dikeluarkan pemerintah seperti: Undang-Undang, maupun Peraturan Pemerintah pada umumnya dapat dipercaya. Dokumen ini merupakan data yang relevan bagi legalitas dan rasionalitas birokrasi. Pada tahap ini penulis melakukan proses verifikasi bahan dokumen atau sering disebut dengan kolasi, yaitu membandingkan antara beberapa dokumen, sehingga terlihat adanya kesesuaian maupun kontradiksi antar fakta. Dalam kondisi ketika terdapat fakta yang kontradiktif, maka dilakukan seleksi atas derajat keterpercayaan sumber, dengan memilih sumber primer yang dapat dijadikan sumber data yang representative. Dengan demikian, diperoleh fakta sejarah yang dapat dipertanggungjawabkan orisinalitasnya.

Fakta sejarah yang dihasilkan dari proses kritik sumber sejarah bersifat tunggal. Untuk mengaitkan antar sumber dilakukan proses penafsiaran atau interpretasi dan penjelasan hubungan antar fakta (ekplanasi). Interpretasi meliputi interpretasi verbal, interpretasi teknis, interpretasi logis, interpretasi psikologis, dan interpretasi faktual. Eksplansi dilakukan secara deduktif. Ekplanasi deduktif berangkat dari kesimpulan-kesimpulan umum, seperti dalil, hukum, aturan, dan semacamnya baru dicocokkan dengan temuan sejarah. Dalam kaitan dengan penelitian nasionalisasi ini akan berangkat dari aturan-aturan umum dan dikaitkan realitas yang terjadi di lapangan (Wasino, 2006).

Tahap ini merupakan tahap penulisan sejarah berbasis fakta-fakta sejarah yang telah mengalami proses interpretasi dan eksplanasi. Penulisan sebagai tahap akhir dari penelitian ini senantiasa memperhatikan aspek kronologis., sedangkan penyajiannya berdasarkan tema-tema penting dari setiap perkembangan obyek penelitian. aspek-aspek non individu menjadi narasi penting dalam kajian ini dalam bingkai waktu. Dengan demikian digunakan analisis prosesual dan struktural (Kartodirdjo, 992; Kuntowijoyo, 2003: 45).

\section{HASIL DAN PEMBAHASAN}

\section{Embrio Nasionalisasi}

Embrio nasionalisasi adalah "Indonesianisasi". Ia bermula dari proses politik yang berimplikasi pada proses ekonomi dan proses hukum. sebagai sebuah proses politik, nasionalisasi dikaitkan dengan proses "Indonesianisasi" kepemilikan aset milik bangsa asing di Indonesia. Proses ini berawal dari cara berpikir yang telah berkembang puluhan tahun sebelum Proklamasi Kemerdekaan Indonesia sebagaimana tercermin dalam program politik Perhimpunan Indonesia (salah satu pendirinya Bung Hatta yang kemudian menjadi Wakil Preseiden Indonesia), dan pidato politik Bung Karno yang dikenal sebagai "Indonesia menggugat"(Abdullah, 2004). Proses Indonesianisasi tersebut mulai diimplementasikan pada masa pendudukan Jepang di Indonesia, tahun 1942-1945 dan semakin menguat selama revolusi kemerdekaan Indonesia.

Setelah Indonesia merdeka minat para pejuang kemerdekaan untuk membangun ekonomi nasional semakin kuat. Salah satu aspek penting adalah Indonesianisasi kepemilikan aset milik asing terutama warga negara Belanda. John Sutter mengemukakan bahwa ada enam bentuk proses Indonesianisasi, yaitu: (1) pendirian perusahaan-perusahaan baru dalam sektor-sektor yang sebelumnya tertutup bagi orang Indonesia, (2) pemindahan aset yang semula milik perusahaan-perusahaan swasya Koloni- 
al kepada pemerintah Indonesia, (3) pendirian perusahaan-perusahaan milik negara, (4) meningkatnya pengawasan pemerintah atas bisnis milik orang asing, (5) meningkatnya partisipasi orang Indonesia dalam manejemen perusahaan-perusahaan asing, dan (6) pengalihan kepemilikan perusahaanperusahaan milik asing kepada pemerintah Indonesia., (7) pemindahan perusahaan-perusahaan milik swasta asing kepada Indonesia dan organisasiorganisasi Indonesia, (8) meningktanya kepemilikan ekuiti orang-orang Indonesia dalam perusahaan-perusahaan yang didirikan oleh orang-orang asing, (9) kembalinya penguasaan tanah kepada masyarakat Indonesia oleh perusahaanperusahaan asing (Lindblad,2008; John Sutter, 1959).

Nasionalisasi mengacu pada penghapusan pengawasan oleh Belanda dan reorientasi ekonomi Indonesia secara mendasar pada masa dekolonisasi dan selama tahun-tahun segera setelah pengakuan Kemerdekaan Indonesia tahun 1949. Istilah nasionalisasi juga dapat dimaknai menggantikan pegawai-pegawai berkebangsaan Belanda dan para manajer berkebangsaan Indonesia dalam birokrasi dan perusahaan-perusahaan swasta di Indonesia selama berlangsungnya nasionalisasi aset bisnis Belanda pada tanggal 1 Desember 1957. Nasionalisasi membawa dampak perubahan struktural dalam konteks yang lebih luas (Lindblad dalam Journal Indonesian and Humanities, Vol. 4, 2011, hlm. 6).

Secara hukum, nasionalisasi memiliki makna yang cukup spesifik. Konsep ini dibedakan dengan konsepkonsep yang sejenis dan sering disalah artikan, yaitu "konfiskasi, onteigening, dan pencabutan hak". Erades mengemukakan bahwa nasionalisasi merupakan suatu peraturan untuk menerima (dwingt te gedogen) bahwa hak -hak atas sesuatu atau beberapa macam benda yang dimiliki oleh orang atau kelompok orang beralih kepada negara. Berdasarkan argumentasi itu, S. Gautama mengemukakan bahwa nasionalisasi merupakan cara peralihan hak dari pihak swasta kepada negara secara paksa. Dengan demikian, nasionalisasi merupakan "spesies" dari asal-usul pencabutan hak (ontegeining) (Gautama, S., 1975).

Istilah ontegeining secara legal pertama kali muncul dalam Undangundang Dasar Sementara. Pasal 27 dari undang-undang itu nyatakan bahwa pencabutan hak untuk kepentingan umum tidak diperbolehkan, kecuali dengan mengganti kerugian dan menurut undang-undang. Dengan demikian, kata ganti "rugi" telah membuka kran bagi sebuah proses diperbolehkannya "pencabutan hak" yang menjadi dasar hukum bagi terbitnya undang-undang nasionalisasi.

Konsep ontegeining lain yang berhimpitan dengan adalah "konfiskasi". Ada kesamaan dengan konsep ontegeining yaitu sama-sama "pencabutan hak", tetapi tanpa ganti rugi. Proses ini juga merupakan proses nasionalisasi seperti yang terjadi di Meksiko pada tahun 1940 (Gautama, 1975; Wasino, dkk, 2014: 3-11).

\section{Proses Nasionalisasi}

Lahirnya pemerintah baru, Indonesia pasca kemedekaanya membawa konsekuensi dalam pengelolaan aset kolonial, terutama Kolonialisme Belanda. Aset-aset ekonomi kolonial diusahakan oleh para pejuang kemerdekaan untuk beralih menjadi aset negara dan bangsa Indonesia. Proses peralihan aset berlangsung dengan dua cara, yaitu peralihan kelembagaan dari Pemerintah 
Kolonial Belanda ke Pemerintah Indonesia dan Nasionalisasi atau Indonesianisasi (Sutter, 1959:1). Peralihan kelembagaan umumnya terjadi di lingkungan lembaga pemerintahan, yakni dari lembaga pemerintahan Hindia Belanda ke Pemerintah Republik Indonesia. Sementara nasionalisasi ditujukan pada asetaset non pemerintahan, baik milik swasta asing maupun badan usaha milik pemerintah Hindia Belanda. Proses peralihan kelembagaan berlangsung beberapa saat setelah Indonesia merdeka, sementara itu proses nasionalisasi terjadi dalam proses kemudian dan mencapai titik puncaknya pada tahun 1957.( Dick, et al., 1999:14).

Inisiatif nasionalisasi semua berasal dari rakyat, terutama yang terkait dengan pendukung partai-partai politik. Partai Komunis Indonesia (PKI) merupakan partai politik yang banyak menggerakkan pendukungnya untuk melakukan pengambilalihan aset-aset milik asing tersebut. Semangat nasionalisasi oleh rakyat Indonesia semakin menguat setelah terjadinya Konferensi Meja Bundar (Kanumoyoso, 2001: 9). Salah satu klausul dari KMB adalah pengembalian Irian Barat (sekarang Papua) ke dalam pangkuan Republik Indonesia. Akan tetapi ada kesan Pemerintah Belanda tidak serius merealisasikan hasil konferensi itu. Akibatnya masa rakyat bergelora dengan sentimen anti Belanda. Sentimen meluas hingga anti terhadap kepemilikan Belanda di Indonesia. Akibatnya ada sejumlah aksi sepihak pengambil-alihan aset-aset perusahaan Belanda, termasuk lahan usahanya. Untuk mengatasi kekacauan itu maka pemerintah Indonesia melakukan nasionalisasi aset-aset perusahaan asing, terutama Belanda yang ada di Indonesia. Tim eksekuasi nasionalisasi adalah pihak Angkatan Bersenjata (TNI), terutama dari unsur Angkatan
Darat (Hariyono, Jurnal Ekonomi dan Manajemen Volume 8 No.1: 127). Setelah tahun 1957, banyak perusahaan Belanda beralih menjadi perusahaan Indonesia. Bahkan sebagian besar BUMN yang kini ada merupakan transformasi dari nasionalisasi tersebut.

Pemerintah Indonesia telah mengeluarkan produk hukum untuk melegalkan nasionalisasi tersebut. Secara legal formal, proses nasionalisasi didasarkan pada pelaksanaan UU No. 86 Tahun 1958 tentang Nasionalisasi Perusahaan-Perusahaan Milik Belanda. Dalam Undang-undang pasal 1 dijelaskan bahwa: Perusahaan-perusahaan milik Belanda yang berada di wilayah Republik Indonesia yang akan ditetapkan dengan Peraturan Pemerintah dikenakan nasionalisasi dan dinyatakan menjadi milik yang penuh dan bebas Negara Republik Indonesia (Undangundang Republik Indonesia No. 86 Tahun 1958 ). Proses nasionaliassi tersebut menjadi tanggung jawab Pemerintah Indonesia dan ditujukan untuk memperoleh keuntungan negara dalam rangka pembangunan ekonomi nasional dan pada akhirnya akan dapat memberikan manfaat sebesar-besarnya bagi masyarakat Indonesia pada umumnya. Dengan demikian tujuan utama pemerintah Indonesia melakukan nasionalisasi terhadap perusahaan-perusahaan milik Belanda itu adalah lebih memperkokoh potensi ekonomi nasional Indonesia, juga untuk melikuidasi kekuasaan ekonomi kolonial, dalam hal ini ekonomi kolonial Belanda (Lindblad, 2008: 105). Perusahaan-perusahaan yang dinasionalisasi pada dasarnya adalah segala perusahaan milik Belanda yang berada di dalam wilayah Republik Indonesia, baik ia merupakan pusatnya maupun cabangnya (penjelasan umum).

Sebagai peraturan pelaksanaan dari UU No. 86 tahun 1958, pada tahun 1959 dikeluarkan Peraturan Pemerintah 
No. 2 tahun 1959 tentang pokok-pokok pelaksanaan UU No. 86 Tahun 1958 tentang Nasionalisasi PerusahaanPerusahaan Milik Belanda. Peraturan Pemerintah No. 2 Tahun 1959 ini, menyatakan bahwa perusahaanperusahaan milik Belanda yang dapat dikenakan nasionalisasi adalah: Pertama, perusahaan yang seluruhnya atau sebagian merupakan milik perseorangan warga negara Belanda dan bertempat kedudukan dalam wilayah republik Indonesia; Kedua, perusahaan milik sesuatu badan hukum yang seluruhnya atau sebagian modal perseroannya atau modal pendiriannya berasal dari perseorangan warga negara Belanda dan badan hukum itu bertempat kedudukan dalam wilayah Republik Indonesia; Ketiga, perusahaan yang letaknya dalam wilayah RI dan merupakan milik sesuatu badan hukum yang bertempat kedudukan dalam wilayah negara kerajaan Belanda. Sementara itu perusahaan-perusahaan yang dikenakan nasionalisasi, termasuk seluruh harta kekayaan dan harta cadangan, hak-hak dan tagihan-tagihan. Namun tidak dijelaskan apakah hak-hak ini harus terletak di dalam wilayah Republik Indonesia (Peraturan Pemerintah Republik Indonesia Nomor 2 Tahun 1959; Wasino, dkk. , 2014: 3-11).

\section{Implementasi Nasionalisasi}

Secara formal untuk melaksanakan nasionalisasi perusahaanperusahaan Belanda di Indonesia sebagaimana diamanatkan dalam Undang-undang Nomor 86 tahun 1958 maka perlu dibentuk lembaga yang mengatur serta mengawasi kelancaran dari jalannya nasionalisasi tersebut. Terkait dengan hal itu, maka Pemerintah Indonesia membentuk Badan Nasionalisasi dan disingkat
Banas. Pembentukan badan ini didasarkan pada Peraturan Pemerintah No. 3 tahun 1959 (dimuat dalam Tambahan Lemabaran Negara Republik Indonesia tahun 1959 No. 1731 dalam Tambahan Lembaran Negara Republik Indonesia No. 1737 tahun 1959).

Banas dibentuk dengan tujuan "untuk menjamin koordinasi dalam pimpinan, kebijaksanaan dan pengawasan terhadap perusahaanperusahaan produktivitet perusahaanperusahaan milik Belanda yang telah dikenakan nasionalisasi dapat tetap dipertahankan dan dipertinggi". Dengan demikian tujuan dari badan ini adalah untuk terjaminnya pengelolaan aset ekonomi Nasional yang diperoleh melalui proses nasionalisasi perusahaanperusahaan Belanda.

Banas berkedudukan di Jakarta (pasal 1). Menurut penjelasan dari pasal $1 \mathrm{itu}$, terlihat bahwa dasar penunjukkan kota Jakarta sebagai tempat kedudukan Banas adalah karena Pusat Pemerintahan maupun badan-badan penampung perusahaan-perusahaan milik Belanda yang diambil alih oleh pemerintah itu ada di Jakarta. Dengan demikian maka keputusan-keputusan pemerintah tentang soal-soal yang mengenai nasionalisasi dapat dengan cepat diteruskan kepada Banas untuk diolah lebih lanjut dan kemudian dapat dengan cepat pula diteruskan kepada Badan-badan Penampung yang telah ada untuk dilaksanakan.

Banas terdiri dari tiga unsur, yaitu: pimpinan, staf, dan sekretariat. Berdasarkan pasal 2 dari PP ini, Pimpinan Banas terdiri atas: Pertama, Dewan Pimpinan yang terdiri atas (1) Perdana Menteri sebagai Ketua, (2) Menteri Keuangan sebagai Wakil Ketua I, (3) Menteri Negara Urusan Stabilisasi Ekonomi sebagai Wakil Ketua II, (4) Menteri Perdagangan sebagai anggota, (5) Menteri Perindustrian sebagai anggota, (6) 
Menteri Pertanian sebagai anggota, (7) Menteri Pekerjaan Umum dan Tenaga sebagai anggota, (8) Menteri Kehakiman sebagai anggota, (9) Menteri Pelayaran sebagai anggota, (10) Menteri Kesehatan sebagai anggota, (11) Menteri Perburuhan sebagai anggota, (12) Menteri Perhubungan sebagai anggota, (13) Gubernur Bank Indonesia sebagai anggota. Kedua, Pimpinan Harian yang terdiri atas (1) Menteri Keuangan, (2) Menteri Negara Urusan Stabilisasi Ekonomi, (3) Wakil Kementerian Pertahanan. Selain itu, terdapat Staf Banas yang terdiri atas (1) Staf Ahli yang bertindak sebagai Perencana (P- 1), (2) Dewan Direktur bertindak sebagai Pelaksana (P-2), (3) Dewan Pengawas (P-3).

Banas merupakan suatu badan yang langsung berada di bawah Perdana Menteri. Ia mempertanggungjawabkan pekerjaan penguasaan, perencanaan, dan pengawasan perusahaan-perusahaan Belanda. Sesuai dengan penjelasan pasal 2 sari PP ini, lembaga tersebut terdiri dari organorgan yang berkaitan dengan fungsi Banas, yaitu organ yang memiliki tugas memimpin dan mempertanggungjawabkan, merencanakan, melaksanakan dan mengawasi.

Berdasarkan penjelasan dari pasal 2 ini, yang dimaksdud dengan Badan/ Panitia Penampung Nasionalisasi adalah antara lain (1) Badan Urusan Dagang (BUD), (2) Badan Pusat Penyelenggaraan Perusahaan-perusahaan Industri dan Tambang (BAPPIT), (3) Pusat Perkebunan Negara Baru (PPN Baru), (4) Badan Pusat Penguasa Perusahaanperusahaan Pharmasi (BAPPHAR), (5) Badan Penguasa Pengangkutan (BPP), (6) Panitia Penguasa N.V. K.P.M. (PPKPM), (7) Badan Pusat Pengawas Perusahaan-perusahaan Pemborongan Belanda (BP5B), (8) Penguasa Perusahaan-perusahaan Listrik dan Gas (P3LG), (9) Badan Penguasa Perusahaan
Asuransi Kerugian Belanda (BPPAKB), (10) Badan Penguasa Perusahaan Pertanggungan Asuransi Jiwa Belanda (BPPDB), (11) Badan Penguasa Kantor Akuntan dan Kantor Administrasi Partikelir Belanda (BPKAKPB), (12) Badan Pengawas Bank-Bank Pusat, (13) Badan Pengawas Perusahaan Kementerian Perhubungan, (14) Panitia Penguasa Perusahaan-perusahaan Maritim Belanda.

Dewan Pimpinan Banas mempunyai tugas menetapkan keseragaman kebijaksanaan dalam pelaksanaan nasionalisasi perusahaan-perusahaan milik Belanda, tugas tersebut antara lain: Pertama, menentukan garis kebijaksanaan dan mengawasi Badanbadan Penampung termaksud pasal 2 ayat (5) dalam lapangan managemen yang meliputi: (1) Urusan Teknis; (2) Urusan Komersiil; (3) Urusan Finansiil; (4) Urusan mempertinggi Produksi dan Produktivitet; (5) Urusan Organisasi dan Administrasi; (6) Urusan Sosial. Kedua, menentukan perusahaanperusahaan milik Belanda yang dikenakan nasionalisasi yang diselenggarakan oleh Pemerintah Pusat dan Pemerintah Daerah tingkat I. Ketiga, menampung dan menyelesaikan persoalan-persoalan yang timbul sebagai akibat Undang-undang nasionalisasi Perusahaan Belanda yang berhubungan dengan soal-soal pemindahan / pembebanan hak milik serta yang mengenai peraturan-peraturan, keputusan-keputusan dan ketentuanketentuan lain dari Penguasa Perang. Keempat, menentukan soal-soal yang penyelesaiannya dan/atau pengurusannya didelegasikan kepada Pimpinan Harian.

Implementasi di lapangan dalam proses nasionalisasi dilakukan oleh Dewan harian. Pasal 4 menyatakan bahwa "Pimpinan Harian melaksanakan soalsoal prinsipiil yang telah diputuskan 
oleh Dewan Pimpinan; Mendorong kegiatan bekerja sehari-hari; Mengkoordinasikan Staf Banas; Memberikan saran tentang soal-soal yang mempunyai sangkut-paut dengan pelaksanaan nasionalisas perusahaanperusahaan milik Belanda. Banas bertanggung jawab kepada Dewan Menteri (pasal 5).

Persoalan penting terkait lain dari proses nasionalisasi perusahaanperusahaan Belanda di Indonesia adalah persoalan ganti rugi. Untuk Kepentingan tersebut dibenuklah Panitia Penetapan ganti kerugian. Tugasnya mengurus persoalan ganti bagi perusahaan-perusahaan asing yang terena dampak nasionalisasi (Peraturan Pemerintah No. 9 tahun 1959).

Panitia penetapan ganti kerugian memiliki beberapa tugas. Sebagaimana disebutkan dalam pasal 1 Peraturan pemerintah ini, tuganya adalah: (1) mengadakan pemeriksaan seperlunya tentang keadaan perusahaan Belanda yang dikenakan nasionalisasi dan menetapkan besarnya ganti kerugian yang dapat diberikan, (2) memberitahukan hasil pekerjaannya kepada Badan Nasionalisasi Perusahaan Belanda. Hasil penetapan ganti kerugian yang ditetapkan oleh panitia ini atau oleh Mahkamah Agung kemudian akan dimuat dalam Lembaran Berita Negara (ayat 3).

Proses penetapan ganti kerugian dapat diajukan secara aktif oleh perusahaan yang terkena nasionalisasi. Pasal 2 dari Peratutan Pemerintah No. 9 tahun 1959 menyebutkan bahwa permintaan ganti kerugian harus disertai dengan bukti-bukti yang sah tentang: (a) hak milik kepunyaan pemohon; (b) kewarganegaraan pemohon; (c) besarnya ganti kerugian yang dimintanya; dan (d) lain-lain keterangan yang dianggap perlu untuk memperkuat permintaannya. Berdasarkan usulan dari perusahaan yang terkena nasionalisasi itu, Panitia Penetapan Ganti Kerugian dapat mengusulkan kepada Badan Nasionalisasi Perusahaan Belanda agar supaya sebagian dari pendapatan yang diperoleh dari perusahaan yang dikenakan nasionalisasi, disediakan untuk pembayaran ganti kerugian pada waktunya (Pasal 3).

Dalam melaksanakan tugasnya, Panitia Ganti Kerugian tidak harus bekerja sendiri. Pasal 4 dari Peraturan Pemerintah ini mengatur bahwa: (1) dalam melaksanakan tugasnya Panitia Penetapan Ganti Kerugian dapat meminta bantuan dari semua instansi dan setiap orang yang dianggap perlu, termasuk pemilik perusahaan yang bersangkutan (ayat 1); (2) Semua instansi dan setiap orang yang dimaksudkan pada ayat (1) diwajibkan memberikan bantuannya; (3) Kewajiban memberi bantuan dan memberikan keterangan kepada yang berwajib dikecualikan bagi mereka yang dilindungi oleh ketentuan yang tercantum dalam pasal 18 ayat (1) dan (2) Undang-undang Keadaan Bahaya. Pasal 4 diperkuat dengan ketentuan dalam pasal 5 yang isinya "Dengan tidak mengurangi ketentuan yang tercantum dalam pasal 4 ayat (3), barang siapa menolak atau sengaja melalaikan untuk memenuhi kewajiban-kewajiban yang termaktub dalam pasal 4 ayat (2), dihukum dengan hukuman penjara selama-lamanya tiga tahun dan/atau denda setinggi-tingginya Rp. 75.000,(tujuh puluh lima ribu rupiah) (dimuat dalam Lembaran Negara Republik Indonesia tahun 1959 no. 16).

Secara aturan, nasionalisasi perusahaan-perusahaan asing memang sudah dibuat sedemikian detail. Akan tetapi dalam implementasinya proses ganti rugi dalam rangka nasionalisasi perusahaan-perusahaan asing tidak selalu berjalan mulus. Persoalan ketersediaan dana pemerintah, konflik politik 
antara Indonesia-Belanda yang menyangkut Irian Barat (Papua), dan resistensi politik dalam negeri terhadap Belanda merupakan faktor-faktor penghambat proses ganti rugi tersebut.

\section{SIMPULAN}

Nasionalisasi Perusahaanperusahaan asing merupakan antiklimaks dari konflik-konflik politik antara Indonesia dan Belanda di satu pihak dan perdebatan pemikiran ekonomi di antara pendiri bangsa. Pilihan terakhirnya adalah nasionalisasi. Nasionalisasi dipandang sebagai cara untuk menegakkan harga diri bangsa, dan menunjukkan kemandirian ekonomi.

Proses nasionalisasi ternyata menimbulkan konsekuensi secara hukum dan ekonomi yang luar biasa. Persoalan ganti rugi akibat pengambilalihan aset perusahaan asing tersebut menjadi perusahaan milik pemerintah Indonesia. Setelah terbentuk Badan Nasionalisasi baru dirasakan bahwa dana yang diperlukan untuk ganti rugi sangatlah besar, pada hal banyak diantara perusahaan tersebut yang nilai ekonominya sudah tidak sepadan dengan ganti rugiyang harus diberikan. Akibatnya pada tahun 1960-an muncul wacana untuk tidak membayar ganti rugi dari perusahaanperusahaan yang dinasionalisasi tersebut. Wacana itu didengungkan terutama dari partai-partai politik pendukung Sukarno, taruhlah PNI dan PKI.

Pembangkangan terhadap ganti rugi akibat nasionalisasi tersebut di satu sisi telah melahirkan semangat anti asing paad era tahun 1960-an. Meskipun berakibat terjadinya kekacauan politik pada tahun 1965 yang menandai perubahan politik dari Sukarno Suharto.

Suharto memandang dengan cara berbeda tentang konsep nasionalisasi. Sebagai bangsa yang punya harga diri, hutang-hutang akibat nasionalisasi harus dibayar. Akibatnya selama puluhan tahun era pemerintahan Suharto, dana pinjaman Indonesia sebagian digunakan untuk talangan ganti rugi nasionalisasi tersebut dan diperkirakan hutang kepada perusahaan-perusahaan Belanda baru lunas pada tahun 2002.

Sebagian besar perusahaanperusahaan yang dinasionalisasi tersebut sekarang sebagian besar berada di bawah Kementerian BUMN. Sayang sekali banyak di antara aset hasil nasionalisasi tersebut yang berkurang akibat salah manajemen atau dengan sengaja dijual kepada pihak asing dengan dalih investasi.

\section{DAFTAR PUSTAKA}

Abdullah, Taufik. 2004. "Indonesianisasi". Makalah dalam Workshop on the Economic Side of Decolonization, Yogyakarta, 18-19 Agustus 2004.

Dick, H.W. et al., The Emergence of National Economy: an Economic History of Indonesia, 1800-2000. Passau.

Gautama, S. 1975. Segi-segi Hukum Internasional Pada Nasionalisasi di Indonesia. Bandung: Alumni.

Hariyono, "Nasionalisasi dan Kontraksi Ekonomi Indonesia di Akhir Tahun 1950-an" dalam Jurnal Ekonomi dan Manajemen Volume 8 No.1, hlm. 127.

Kanumoyoso, Bondan. 2001. Nasionalisasi Perusahaan Belanda di Indonesia. Jakarta: Sinar Harapan.

Kartodirdjo, Sartono. 1992. Pendekatan Ilmu Sosial dalam Metodologi Sejarah. Jakarta: Gramedia.

Kuntowijoyo. 2003. Metodologi Sejarah. Yogyakarta: Tiara Wacana.

Lindblad, J. Thomas. 2008. Bridges to New Business: the Economic Decolonization of Indonesia, Leiden: KITLV.

------. 2011. "The Economic Decolonization of Indonesia: a Birds' Eye View" dalam Journal Indonesian and Humanities, Vol. 4, 2011, hlm. 6.

Peraturan Pemerintah Republik Indonesia Nomor 
Nasionalisasi Perusahaan-Perusahaan ... - Wasino

2 Tahun 1959 Tentang Pokok-Pokok Pelaksanaan Undang-Undang Nasionalisasi Perusahaan Belanda

Peraturan Pemerintah Republik Indonesia Nomor 3 tahun 1959 tentang Pembentukan Badan Nasionalisasi Perusahaan Belanda

Peraturan Pemerintah Republik Indonesia no. 9 tahun 1959 tentang Tugas Kewajiban panitia Penetapan Ganti Kerugian Perusahaan-perusahaan Milik Belanda yang dikenakan Nasionalisasi dan cara Mengajukan Permintaan Ganti Kerugian Sjamsuddin, Helius. 2006. Metodologi Sejarah. Yogyakarta: Ombak.

Soejono , R.P. dan R.Z. Leirissa (Editor). 2008.. Sejarah Nasional Indonesia VI: Zaman Jepang dan Zaman Republik Indonesia (1942-1998). Jakarta: Balai Pustaka.
Sutter, John. 1959. "Indonesianisasi: A Historical Survey of the Role of Politics in the Institutions of a Changing Economi from the Second World War to Eve of the General Election, 1940-1955" PhD Thesis, Cornell University, Ithaca, New York.

-----. 1959. Indonesianisasi: Politic in a changing Economy, 1940-1955. Ithaca: Cornel University.

Undang-undang Republik Indonesia No. $86 \mathrm{Ta}$ hun 1958 Tentang Nasionalisasi Perusahaan-perusahaan Milik Belanda

Wasino. 2007. Dari Riset hingga Tulisan Sejarah. Semarang: Unnes Press

Wasino dkk., 2014. Sejarah Nasionalisasi AsetAset BUMN: Dari Perusahaan Kolonial menuji Perusahaan Nasional. Jakarta: Kementerian Badan Usaha Milik Negara republik Indonesia. 